Portland State University

PDXScholar

Summer 2021

\title{
How to Decide Whether and How to Sell a Small Family Business
}

Gabriel Harlow

Portland State University

Follow this and additional works at: https://pdxscholar.library.pdx.edu/honorstheses

Part of the Entrepreneurial and Small Business Operations Commons, and the Other Business Commons

Let us know how access to this document benefits you.

Recommended Citation

Harlow, Gabriel, "How to Decide Whether and How to Sell a Small Family Business" (2021). University Honors Theses. Paper 1145.

https://doi.org/10.15760/honors.1176

This Thesis is brought to you for free and open access. It has been accepted for inclusion in University Honors Theses by an authorized administrator of PDXScholar. Please contact us if we can make this document more accessible: pdxscholar@pdx.edu. 
How to decide whether and how to sell a small family business

by

Gabriel Harlow

An undergraduate honors thesis submitted in partial fulfillment of the requirements for the degree of

Bachelor of Science

in

University Honors

and

Management and Leadership

Thesis Advisor

Jeanne Enders

Portland State University 


\section{How to decide whether and how to sell a small family business}

\section{Introduction.}

The target audience for this paper are the families that own small businesses and are trying to figure out, "now what?". Within this paper is a look into the motivations for selling businesses, decision making models that can help these families decide, and analysis into why one should lean towards keeping their business or parting ways with it. This paper will also cover such questions as figuring out if one should pursue employing someone else to carry the bulk of the work so that you can still maintain ownership or if it would be more profitable to sell outright. Other things covered will be if a business can even be sold at all, evaluation theory, personal interviews with business owners, and advice on increasing the value of a business. In some cases a successful business may have no sale value, such as some consulting businesses. (1)

\section{Why would you sell a small business?}

The reasons for selling a small business can be broken up into a need for emotional fulfillment and financial fulfillment. As people get close to or past a traditional retirement age, the question of how long can one continue to do this begins to linger. This is especially the case in more physical work places. Oftentimes the mistake will be made of not having the business ready to sell and owners will have to juggle running a business they are no longer physically able to run on top of the extra work that goes into getting a business ready to sell. Generally a family business will go in one of three ways after an owner exits a business. Selling, closing, or passing onto a successor. If one sells, that may be in order to invest into another business or to have enough for retirement savings to take care of financial needs for the rest of your life. Closing happens when your business cannot sustain itself financially or it is not able to sell. A business that closes can still recoup some income by selling off assets, such as copying machines, tools, information, etc. This is supported by interviews conducted with two separate business owners on the famous San Francisco, Union Street block. Elias Batshon is an owner of The Sherman Market as well as other corner stores throughout San Francisco. He states that a business should only be sold if it is not profitable and that a truly profitable business can be measured as 
successful if you can afford to hire a full time worker and still maintain a profit. Elias stated that his intent in retirement was not to sell his businesses but maintain a workforce that would handle all the work while he maintains a passive income. Elias states that if you cannot secure a long term lease or if your landlord is untrustworthy, you should sell to protect yourself. (2) Peppina, owner of the Post Box Inc, states that the primary reason to sell when a business is doing well is that you no longer enjoy the work and would like to try a business that interests you. (3)

\section{Passing a business on.}

Passing a business onto a successor but still retaining ownership is a process that involves vetting and proper training. Oftentimes an owner will have an idea of passing a business off to a family member but this does not always work out as the family member may have separate desires from running your business. If you are grooming your successor, have them trained well in advance in case you may fall into poor health or something else happens that may disrupt your ability to participate in the business. A business that would otherwise have cleanly transitioned can completely collapse if the owner suffers some unforeseen tragedy. One must also realize that the timing of selling a business may never seem right and that it is a very emotional process. (4) One can spend potentially decades building something and finally parting ways with it can cause one to enter a period of transition and confusion.

If you do decide to keep the business by hiring someone to run it and no longer take part in it, you can have a continuous income that can grow with the company and support you in retirement. This is dependent on the security of your lease and ability to maintain a profit while hiring full time workers. This option will not net you a large payout on exit and is riskier, but if the business model is secure, it is a sound option. On the other hand, if you are running a volatile business that could potentially lose its profitability quickly, you could lean towards selling.

\section{Decision making tools and understanding your business as a good.}


Decision making tools are an effective way of coming to a decision by applying tangible values and formulating plans to make decisions. This can help when you struggle to come to a conclusion by just thinking on it. One of the models that can be used is The Vroom-Yetton Model, a decision making model designed by Victor Vroom and Phillip Yetton in 1973 in the book Leadership and Decision Making (5). The benefit of this model is in its flexibility. If you are working within a family setting, coming to a decision may or may not be a group decision. Answering the decision tree below will lead you to which leadership model might work most effectively.

A1 (Autocratic 1) - Make a decision with the information you have without consulting anyone.

A2 (Autocratic 2) - Consult team for additional information and then make a decision.

C1 (Collaborative 1) - Inform the team of your predicament and ask for advice individually, then make a decision on your own.

C2 (Collaborative 2) - You call a group discussion, discuss it with everyone, and then make the decision.

G2 (Collaborative 3) - Work with the team to come to a group consensus, primarily acting as a facilitator. 


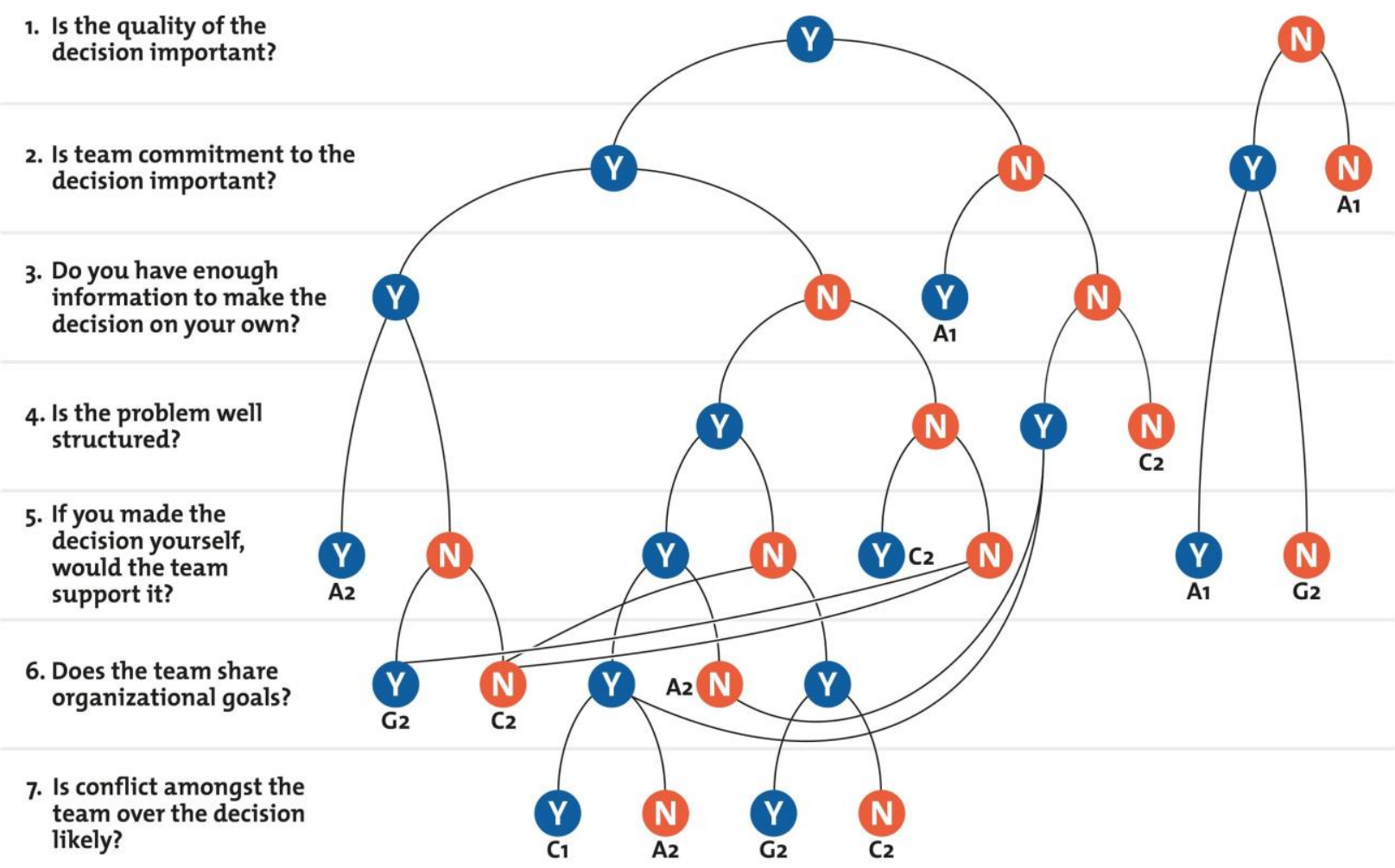

(The Vroom-Yetton Decision Tree: Adapted from Leadership and Decision Making by Victor H. Vroom and Philip W. Yetton by permission of the University of Pittsburgh Press. Copyright $\odot 1973$ University of Pittsburgh Press.) (6)

Another model in which to better understand your business in relation to its competitors is a SWOT analysis. By analyzing your businesses through its strengths, weaknesses, opportunities, and threats, you put yourself in a better position of understanding both the true value of your company and its relative value towards similar businesses.

\section{Evaluations, understanding the value of your business.}

Evaluations for a business can be conducted individually or by hiring a professional. Evaluations at a professional level are typically only conducted for larger businesses as the process typically runs between $\$ 3,000$ to $\$ 6,000$ and are generally outdated after six months, especially in the eyes of the IRS. There are three primary consulting models used, most commonly used for small businesses is an asset based evaluation. Which is the value of liquidating assets after paying off creditors. Another asset to consider is your customer base. Do you have a lot of subscribers in your business model? An underrated asset in The Post Box Inc, a P.O box business, is the fact that over 200 people have monthly, quarterly, and yearly subscriptions. (Liska, Michael, professional evaluator, Personal Interview 7/21)(7) It is important to try to raise the value of your 
business as much as possible before receiving the evaluation. This can be done through intensive ad campaigns, standardizing business processes that will allow for a fluid hand off of the business to another party, and to increase business as much as possible. It is also important to have the knowledge of how the business is run. Without it, a business is worth significantly less as information is a part of the sales process. Another evaluation model is to simply look at how much a similar business is. Although this gives you a ballpark estimate, it is always a good place to start in negotiations when selling a business. Another decision matrix that could be used to determine whether you want to sell or not is a weight decision matrix. Other Names for it are a Grid Analysis or a Pugh Matrix Analysis. In the grid below, you could choose your options and weigh the factors that are important to you. Once you have evaluated a score and weight to these factors, you add up that tally in the end and it should help you pick an option based on the highest score and also to help you discount other options.

\begin{tabular}{|c|c|c|c|c|c|c|}
\hline & Competency & Cost & Viability & Desirability & Alignment & Total \\
\hline Criteria rating & 3 & 4 & 5 & 4 & 2 & \\
\hline Idea A & 1 & 3 & 3 & 1 & 1 & \\
\hline Weighted rating & 3 & 12 & 15 & 4 & 2 & 36 \\
\hline Idea B & 5 & 3 & 5 & 3 & 4 & \\
\hline Weighted rating & 15 & 12 & 25 & 12 & 8 & 72 \\
\hline Idea C & 1 & 2 & 3 & 1 & 1 & \\
\hline Weighted rating & 3 & 8 & 15 & 4 & 2 & 32 \\
\hline Idea D & 5 & 1 & 2 & 1 & 1 & \\
\hline Weighted rating & 15 & 4 & 10 & 4 & 2 & 35 \\
\hline
\end{tabular}

(https://www.designorate.com/decision-matrix-decision-making/, (8) 


\section{Standardization.}

Before you sell a business, it is good to have it running as efficiently as possible to present. A business that is inefficient is a difficult sell. That is because a business must be able to switch hands without the other party having to figure out how to run a new business. What is the point of purchasing a restaurant without getting any of the recipes that made it succeed? Although the best idea is to have already made these processes simple for one's self, it is important to improve processes for sale. It is also important to hire an accountant to help facilitate the sale and to learn local and state tax laws in order to get the best value for the business. Peppina Harlow, owner of Post Box Inc. states that it is an important factor to her that whoever runs the business takes care of the customers and maintains the level of service to its community. To her, it is not just about the money but about taking care of the elderly, as they are one of the primary demographics to use a postal service.

Once a business has been readied for sale, it is important to get an evaluation on the worth of your business. You can pursue an adjusted net asset method, CCF, DCF, or market based valuation. (9) It is also important to consider the intangible assets that a business possesses. Is the business the only one of its type in its area? Does it have a strong reputation? These are all factors that can contribute favorably to a valuation of a company. Once the business is prepped, now is the time to put it up for sale. Putting a business up for sale can go through many avenues for sales. Competitors could be called, utilizing a developed business network to ask around, business brokerages, and even customers can be considered. In selling a business, you must prepare yourself for the severing of bonds formed in business. "To witness neighbors come and go,either by life choices or through death, is an amazing experience." So how do you find someone? Peppina states that she is in contact with people she has met through her business that shows that they not only have the money to purchase the business, but genuinely care and are a part of the community. (10) Forbes recommends a broker as long as you are sure of their qualifications and talk to the broker. Asking how they intend to sell the business and how successful they have been in the past of successful sales. (11) 


\section{The act of selling a business.}

If you have decided to sell, the company must be in a condition to sell and function well. This means it must have a proven value, proof that it can retain value, and assets in which to pass on. You must then be able to sell someone on the value of the business through a presentation of the processes and have financial numbers readily available. You must find a buyer, either through your local community or through securing the help of a broker. Oftentimes the connections you build in your community will reveal itself someone who will either offer to purchase your business or can at the very least enter a discussion on the merit that they know your business and it has demonstrated value. It is important to consider that selling a business is something that takes a considerable amount of work and can sometimes take at least a year of preparation, sometimes it can stretch out for years. You must also decide whether you would like to negotiate the sale of your business or have someone do it on your behalf. While you may secure a higher theoretical payout with someone negotiating for you, there will also be brokerage fees. This can either be a lump sum payout or a percentage payout, although it can also be both. You have to factor in the value of assets into the sale as well. For example, if The Post Box, Inc. is going to sell their business, they are not only selling the space, the clients, and the knowledge, but also the assets of having physical P.O boxes which can be worth thousands of dollars from a pure asset standpoint. Make sure that you have a longer lease, a month to month lease can be a death sentence for selling a business.

\section{Conclusion.}

In conclusion, preparing properly for a sale can be the difference between a complete loss or firesale and a well maneuvered and profitable business exit. That is after all, deciding that a business would not be better to be held onto with different workers and you stepping away to enjoy retirement. Set your criteria for selling and for what you will need to hand leadership over to someone else. If you are unable to find suitable offers from those around you, consider using a broker, but make sure that they have a good track record and that they lay out a plan for getting your business out there. Preparation and connections as well as getting a proper evaluation of similar businesses will also ensure that you make the best exit you can. If you are torn about your 
options, use decision making models. A business is a powerful tool and can be maintained even in retirement with the right people and finances. 


\section{Works Cited}

1. Grebey, James F. (2018). Moving On: Getting the Most from the Sale of Your Small Business. DEG Press.

2. Batshon, Elias. personal interview, 6/2/2021.

3. Nemethy, Les. (2011). An introduction to Business Exit Planning. In Business Exit Planning (pp. 11-21). John Wiley \& Sons, Inc. https://doi.org/10.1002/9781118267837.ch1

4. Seago, W. E. (2018). The tax aspects of acquiring a business (Second edition.). Business Expert Press.

5. the Mind Tools Content Team By the Mind Tools Content Team, et al. "The Vroom-Yetton Decision Model: Deciding How to Decide." Decision Making From MindTools.com, www.mindtools.com/pages/article/newTED_91.htm.

6.(The Vroom-Yetton Decision Tree: Adapted from Leadership and Decision Making by Victor H. Vroom and Philip W. Yetton by permission of the University of Pittsburgh Press. Copyright (C) 1973 University of Pittsburgh Press.)

7. (Liska, Michael, Personal Interview 7/21)

\section{8. (https://www.designorate.com/decision-matrix-decision-making/)}

9. DeNicola, Louis DeNicola is (2020, February 10). Small Business Valuation Methods: How to Value a Small Business. Nav. https:/www.nav.com/blog/small-business-valuation-methodshow-to-value-a-small-business-474215/.

10.Harlow, Peppina. Personal interview. 6/1/2021

11. Say, My. "Selling A Small Business In 30 Days: How One Couple Sold Their Bakery For Six-Figures." Forbes, Forbes Magazine, 5 Jan. 2017, www.forbes.com/sites/groupthink/2017/01/05/selling-a-small-business-how-a-husband-andwife-tean-sold-their-bakery-quickly-and-at-a-high-price/?sh=2e302a5d4c66. 